\title{
КОГНИТИВНО-ПРАГМАТИЧКИ АСПЕКТИ ЗАГОНЕТКИ И ОДГОНЕТКИ
}

Рад анализира когнитивно-прагматичке аспекте загонетке, кратке књижевне и фолклорне форме која се састоји од говорних чинова загонетања и одгонетања. Загонетање и одгонетање се може дефинисати као откривање веза између претпоставки и информација у загонеткама и претпоставки и информација у одгонеткама које нису високо приступачне и јасне у меморији. Теоријска основа за анализу заснива се на принципима релеванције и претпоставци о континуитету дословног, лавабог и метафоричног тумачења језички кодираног значења (SPERBER, WILSON 1995). У основи ових поставки је становиште да комуникација није само кодирање и декодирање значења, већ и комбиновање контекстуалних импликација, помоћу којих се може доћи до оптимално релевантних значења и тумачења језика. Корпус за анализу чине одгонетке на пет српских загонетки, а примери су сакупљени на основу упитника који је попунило 86 изворних говорника српског језика, студената прве године Департмана за англистику на Филозофском факултету у Нишуㄹ․ Имајући у виду да се значења речи и концепата у загонеткама комбинују на различите и оригиналне начине са циљем да се одгонетка више сакрије него открије, рад тестира хипотезу да претпоставке и информације у понуђеним одгонеткама нису увек у јакој инференцијалној вези са претпоставкама и информацијама понуђеним у загонеткама, већ могу бити резултат активирања асоцијативних веза. Циљ рада је да опише различите врсте одгонетки, које су резултат истог, сличног и различитог тумачења веза између речи и концепата у загонеткама, а у вези са тим и да представи неке когнитивно-прагматичке аспекте загонетања и одгонетања. Резултати показују да се одговори на свих пет загонетки могу класификовати у четири различите групе. Такође, истраживање потврђује претпоставку да се неке одгонетке пре могу назвати асоцијацијама, а не резултатом откривања инференцијалних веза између загонетке и одгонетке.

Кључне речи: загонетка, одгонетка, когнитивно-прагматички аспекти, теорија релеванције, реч, концепт, недословна сличност, метафора.

\footnotetext{
${ }^{1}$ milica.radulovic@filfak.ni.ac.rs

2 Упитник садржи и пет загонетки на енглеском језику. У складу са циљевима истраживања, корпус за анализу у овом раду чине само српске загонетке и одгонетке.
} 


\section{1. Увод}

Милошевић-Ђорђевић (1995: 157) дефинише загонетку као „врсту мисаоно-говорне игре, изражене у виду метафоричног - описног или непосредног, често збуњујућег питања које захтева одговор". Загонетка је кратка и стара форма, врста народне умотворине, народне књижевности и „народне фразеологије (КЛЕУТ 2010: 14)”, али, како Самарџија (1995: 6) наводи, историја књижевности указује на то да најстарије записане загонетке припадају писаној литератури. Анализирајући етимологију фолклорног текста, Сикимић (SIKIMIĆ 1996: 24) уочава да је скривени денотат основна специфичност загонетке у односу на друге мале фолклорне форме. У том смислу, одгонетка је резултат погађања денотата на основу извођења закључака поређењем и успостављањем веза између дословних и метафоричних представа и претпоставки у вези са језички кодираним значењима. Тако загонетке, са једне стране, како Лалевић (1995: 155) објашњава, карактерише „краткоћа, сажетост, ритмичност”, али и „тајанственост, замршеност која се каткад провиди, каткад остаје као књига са седам печата”.

У ширем смислу, у овом раду анализирају се когнитивно-прагматички аспекти загонетања и одгонетања на основу принципа и претпоставки теорије релеванције Спербера и Вилсонове (1995). ${ }^{4}$ Анализа корпуса се заснива на претпоставци Спербера и Вилсонове (1995: 234-237; 2008: 84-105) о постојању континуитета, а не дисконтинуитета између дословног, лавабог и метафоричног тумачења језички кодираног значења. Наиме, на основу језички кодираног значења, односно конкретних стимуланса на основу којих се одређени скуп претпоставки и знања чини манифестним, а у случају загонетки што мање манифестним и приступачним, загонетка се разрешава проналажењем веза „дубљег смисла исказаних речи (МИЛОШЕВИЋ-ЂОРЪЕВИЋ 1995: 158)”, које леже у метафоричким и алегоријским проширењима смисла загонетке. Објашњавајући механизме загонетања и одгонетања, Самарџија (1995: 42) такође упућује на то да је трансформација решавања загонетке у основи идентична односу метафоре и дословно схваћеног метафоричног значења. Фоконије и Tарнер (FAUCONNIER, TURNER 2006), аутори теорије концептуалног сажимања/интеграције (енг. Conceptual Blending Theory или Conceptual Integration), користе загонетку као илустрацију потенцијала комбиновања концепата.

\footnotetext{
${ }^{3}$ О синонимима за реч загонетка говори Лалевић (1995: 151-152). Помињу се синоними и везе са речима гонеталииа, гонетка, ганка, дашталииа (последње име према песнику J.J. Змају). Што се тиче синонима за реч одгонетка, то су, на пример, одгонетљај, одговор и ременте.

${ }^{4}$ У својој магистарској тези Naslovi u britanskoj informativnoj štampi u svetlu teorije relevancije, Радуловић (RADULOVIĆ 2011) се бави лексичко-семантичким и синтаксичким аспектима наслова новинских чланака у оквиру теорије релеванције. Исти теоријски оквир Радуловић (RADULOVIĆ 2016) користи и у докторској дисертацији Euphemisms in English and Serbian Public Discourse за анализу еуфемизама.
} 
Из овога следи да је за загонетку и загонетање разлика између речи и концепата кључна. Тако Спербер и Вилсонова (1998: 184-185) сматрају да једна реч може изражавати један или више концепата, више речи могу изражавати један концепт, а може доћи и до неке комбинације наведених механизама. Сам степен поклапања концепата и речи је емпиријско питање. Самарџија (1995: 16), слично томе, упућује на сложеност варијантности загонетке, што значи да се о истом појму може загонетати на различите начине, да о истом појму постоји више различитих загонетки и да се на сличан или скоро исти начин загонета о различитим појмовима. Полазећи од дефиниције загонетки као мисаоно-говорне игре скривања денотата, у овом истраживању загонетање и одгонетање се анализира као питање успостављања и подешавања веза између речи језика којим говоримо и језика мисли. Загонетање и одгонетање се такође посматрају и у вези са разликом између идиосинкратичних тј. нелексикализованих тј. неописивих концепата са једне стране, и стабилних и описивих концепата са друге стране, о којој говоре Спербер и Вилсонова (1998: 189)5 . Пошто се речи и концепти у загонеткама комбинују на иновативне начине са циљем да се одгонетка пре сакрије него открије, у раду се разматра хипотеза да одгонетке нису нужно у инференцијалној вези са загонетком, већ могу бити и резултат активирања асоцијативних веза између загонетке и одгонетке.

\section{2. Теоријски оквир}

У овом делу рада дата је теоријска основа за истраживање. Теоријски оквир рада заснива се на теорији релеванције Спербера и Вилсонове (1995), односно на следећим принципима и претпоставкама: 1) представљени су први, когнитивни и други, комуникативни принцип релеванције (SPERBER, WILSON 1995, 1998); 2) објашњава се однос између језика којим говоримо и језика мисли (CARSTON 2002; SPERBER, WILSON 1995, 1998) и 3) представљена је претпоставка о континууму дословног, лавабог и метафоричног тумачења језички кодираног значења (SPERBER, WILSON 1995, 1998, 2008). Преводи термина који се користе у овој теорији преузети су из глосара ауторке Мишковић-Луковић (MIŠKOVIĆ-LUKOVIĆ 2006: 295-312).

Теорија релеванције заснива се на појму релеванције и принципима релеванције (SPERBER, WILSON 1995: 255-279; 1998: 191-192). Као прво, релеванција је својство улазних информација којима се активирају когнитивни процеси. Обрада улазних информација води ка одређеним ефектима у сазнању, а што су већи ефекти, и ниво релеванције је већи. Међутим, обрада

\footnotetext{
5 Термини описив, неописив, описивост и неописивост су преводи термина effable, ineffable, effability и ineffability које користе Спербер и Вилсонова (1998: 189, 200). Могу се користити и преводи исказив/неисказив и изрецив/неизрещив.
} 
улазних информација захтева ментални напор, тако да се релаванција смањује уколико се ментални напор повећава. У вези са овим, вербалну комуникацију, разумевање и спознајни процеси уопште могу се објаснити помоћу два основна принципа: 1) когнитивни и 2) комуникативни принцип релеванције (енг. cognitive and communicative principles of relevance). Према првом принципу, људска когниција усмерена је ка максималној релеванцији. У светлу претходне дефиниције појма релеванције, то значи да људска когниција тежи ка остваривању што више когнитивних ефеката уз што мањи ментални напор. Тако, на пример, Деспотовић (2019: 99) у загонеткама види добру вежбу за стицање снаге духа јер загонетка тражи веће мисаоно напрегнуће. Према другом принципу, сваки чин демонстративне комуникације ${ }^{6}$ саопштава претпоставку о својој оптималној релеванцији. Оптималност значи да је исказ најрелевантнији могући у односу на способности говорника, али и такав да може довести до вредних когнитивних ефеката уз адекватан напор саговорника. Коначно, треба напоменути и то да, иако се релеванција дефинише у вези са ефектима пажње и намере (KECSKES 2016: 55), сматра се да саговорници комуницирају у складу са принципима релеванције, али без свести о томе (ALLOTT 2013: 80).

Следећа теоријска претпоставка у анализи корпуса тиче се односа између језика којим говоримо и језика мисли. У теорији релеванције овај однос је у вези са појмом инференције, менталног процеса извођења закључака и значења на основу задатог кодираног значења и контекстуалних импликација. Спербер и Вилсонова (2008: 98) указују на разлику између инференцијалног и традиционалнијег асоцијативног приступа метафорама: све инференцијалне везе су асоцијативне, али нису све асоцијације инференцијалне. Имајући у виду инференцијалну природу разумевања, Спербер и Вилсонова (1998: 197-200) заступају становиште да се концепти, као "речи менталног језика", кодирају речима, али и да речи могу, у зависности од контекста, изражавати и друге концепте који су у вези са кодираним концептом. То укратко значи да има много више менталних концепата од речи у језику. У исто време, нису све представе и мисли о објектима, догађајима и стањима стабилни ментални концепти који се могу кодирати тј. исказати, или, једноставније речено, не мора да значи да се концепт задржава у меморији само уколико се језички кодира. Често долази до формирања $\mathrm{ad}$ hoc концепата у специфичним, ad hoc контекстима и ситуацијама. Аутори такође говоре и о томе да се нека својства могу запамтити и без контекстуалних претпоставки које су потребне како за идентификацију концепта, тако и за идентификацију речи која кодира концепт. На пример, можемо

\footnotetext{
${ }^{6}$ Демонстративно-инференцијална комуникација (за разлику од, на пример, прикривене комуникације) се заснива на стимулансу помоћу којег се говорникова намера да прикаже манифестним одређен скуп претпоставки чини узајамно манифестном (MIŠKOVIĆLUKOVIĆ 2006: 295).
} 
препознати осећање, расположење, било какво стање, што значи да постоји стабилни ментални концепт, али немамо увек реч за то. Осим тога, с једне стране, увођење нових речи у језик је друштвено и историјски условљено, a c друге стране, додавање нових концепата није толико ограничено јер је субјективно условљено. Исто тако, различити говорници могу једну те исту реч довести у везу са различитим концептима, без обзира на то што постоји стабилна веза између речи и одређеног концепта.

Концепти имају своје менталне ознаке које воде ка три врсте информација: логички садржај, лексичка својства и енциклопедијске информације које имају различите и променљиве нивое приступачности (SPERBER, WILSON 1995: 86; CARSTON 2002: 321-322). Што се тиче проблема описивости концепта, Спербер и Вилсонова (1998: 200) сматрају да, као прво, има много стабилних и описивих и описаних концепата за које сви знамо, затим да постоје идиосинкратични концепти за које сви знамо јер су део заједничког искуства, али и да постоје и идиосинкратични концепти који не могу бити описани. Претпоставља се да значења речи могу бити различита: неке речи кодирају јасне концепте, а неки кодирају схеме (CARSTON 2002: 363).

Претходна расправа је у вези са претпоставком о континууму дословног, лавабог (недословног) и метафоричног тумачења језички кодираног значења, односно о претпоставци да нема дисконтинуитета између недословне сличности и разних ,фигуративних" употреба у које спадају примери поетских метафора (SPERBER, WILSON 1995: 231-237; 2008: 84-105). Спербер и Вилсонова (2008: 93-95) говоре о различитим врстама континуума значења, као што су, на пример: 1) континуум између оних употреба које се могу окарактерисати као ограничене екстензије категорија, и оних употреба које се могу окарактерисати као креативније екстензије категорија; 2) континуум између хиперболичних и метафоричних употреба речи и 3) континуум између екстензија категорија и метафора. Треба рећи да претпоставка о континууму не значи да аутори негирају чињеницу да се метафоре често истичу као посебно креативна употреба језика (SPERBER, WILSON 2008: 98). Међутим, Спербер и Вилсонова (2008: 102-103) напомињу и то да је многе метафоре лако разумети, а да адекватно дословно разумевање може бити ментално напорније у односу на разумевање недословне сличности или чак метафоричне конструкције. О континууму говори и Самарџија (1995: 28-29). Наиме, ауторка предлаже континуум поступака загонетања. Први и најједноставнији поступак је директно саопштавање одгонетке или фонолошко понављање. Затим, по степену сложености следе: 2) набрајање обележја која се односе на одгонетку; 3) описивање појма који се проширује поређењем са другим појмовима; 4) повезивање више различитих појмова; 5) метонимијска замена предмета једном особином или појмом са којим је у вези и 6) метафорична замена једног појма другим.

Спербер и Вилсонова (1995: 235-237) сматрају да се тумачење метафора базира на принципима и процедурама које важе за вербалну комуникацију 
уопште, тј. да за тумачење метафора нема посебних интерпретативних процедура. Тако постоје речи које имају стабилне везе са менталним концептима, али које такође могу бити употребљене и као метафоре у зависности од контекста. Неметафорична и метафорична тумачења и контекстуалне импликације изводе се на основу истих инференцијалних процедура, које подразумевају формирање и тестирање интерпретативних хипотеза о намераваним денотатима и значењима. У теорији релеванције, процедура разумевања која се базира на тестирању хипотеза до тренутка када се остваре очекивани когнитивни ефекти назива се стратегија разумевања или стратегија најмањег напора (енг. relevance-theoretic comprehension strategy, relevance-guided comprehension procedure или least-effort strategy) (SPERBER, WILSON 1998: 189-197; SPERBER, WILSON 2008: 90-93). Саме метафоре могу бити стандардизоване, као резултат високо приступачних енциклопедијских информација које се активирају употребом одређене речи. Један такав пример је метафорична употреба речи pigsty. Метафоре могу бити, али нису увек стандардизоване, а што је метафора креативнија, ниво менталног напора и одговорности слушаоца/ читаоца у извођењу метафоричних тумачења и контекстуалних импликација је већи. Тумачење значења може се завршити и одустајањем од тестирања интерпретативних хипотеза уколико је напор превелики и не доноси очекивани резултат, што није редак случај приликом одгонетања загонетки.

На крају овог дела рада, треба напоменути да је теорија релеванције већ била оквир за нека истраживања о загонеткама. Јасновски (JASNOWSKI 1991) је један од аутора који примењује теорију релеванције у анализи загонетки у својој докторској дисертацији. Аутор истиче значај контекста за тумачење загонетки, а такође показује да је разумевање и одгонетање загонетки врста хеуристичке активности. Теорија релеванције је такође била теоријски оквир за још једно истраживање у коме се анализирају дословне загонетке и метафоричне загонетке (у раду се користе термини literal riddles и metaphorical riddles), а посебно се истиче значај контекста и културних образаца за разумевање загонетки (MAGACHI 2015). У још једној анализи метафоричних загонетки, ослањајући се на теорију релеванције, аутори истичу значај когнитивног контекста, у које спадају и друштвени и културни аспекти и искуства (HUSSEIN, ABDULLAH 2016). Аутори указују и на то да, у поређењу са котекстом и ситуационим контекстом, когнитивни контекст има значајнију улогу у интерпретацији загонетки.

\section{3. Анализа корпуса}

Сикимић (2011) разматра питање плуралитета денотата у вези са дијахронијским, дијатопијским и контекстуалним факторима. У књизи Српске народне приповијетке и загонетке из 1897. године, збирци загонетки које је сакупио и издао Вук Стефановић Караџић, Ђ. С. Ђорђевић (стр. 423) на- 
води и то да за неке загонетке или нема одгонетљаја или се каже да се не зна. Ослањајући се на рад Бен-Амоса (BEN-AMOS 1976), Сикимић (2011: $595)$ скреће пажњу на то да нема једног, јединог, истинског и објективног одговора на загонетку. Свако питање има различита могућа решења, и свако од њих може одговарати метафоричном опису. Тако је свако појединачно решење валидно уколико га даје изворни говорник језика који припада одређеној културној заједници, односно има културну и језичку компетенцију. Сикимић (2011: 595) такође подсећа на Бен-Амосово (1976) разматрање логике загонетке као пре свега укорењене у језику мисли и искуству друштвене заједнице, што је у директној вези са разматрањима о односу између језика говора и језика мисли у оквиру теорије релеванције.

\section{1. Корпус}

Корпус за анализу сачињен је на основу одговора на пет српских загонетки које су преузете са интернета (загонетке је послала Андријана Настасијевић)7: 1. Ако изговории моје име, више ме неће бити; 2. Говори без уста и језика; 3. Ја чувам благо, а људи мене чувају, 4. Никада га није било, никада га неће бити, а још увек га има и 5. Цео дан иде, а никуд не одмиче. Загонетке су биране насумично, без претходног просуђивања о формалним карактеристикама, формалној логици и класификацијама загонетки. Такође, говорницима-погађачима одгонетки није дата никаква помоћ у смислу визуелних или било каквих других стимуланса. ${ }^{8}$ Одговоре на загонетке дало је 86 изворних говорника српског језика, студената прве године Департмана за англистику на Филозофском факултету у Нишу. Пре него што су дали своју одгонетку, студенти су одговорили на питање да ли први пут чују загонетку или не. Уколико је одговор био да, говорници-погађачи су уписали своје решење загонетке, а уколико је одговор био не, говорници-погађачи су уписали већ познато решење.

\section{2. Методе и циљеви}

С обзиром на то да се загонетке формулишу на основу веза између речи и концепата у загонеткама и одгонеткама које нису високо приступачне у меморији, потврдило се очекивање да неће сви говорници, њих 86, дати сва решења за све загонетке. С тим у вези, направљена је класификација која се састоји од четири типа одгонетки, обележене као групе А, Б, В и Г: А) одгонетка није позната и није понуђена; Б) одгонетка није позната и

\footnotetext{
${ }^{7}$ Страница са које су преузете загонетке налази се на интернет адреси: https://www.boske.rs/ stranice/zagonetke.html

${ }^{8}$ У свом истраживању мултимодалних аспектата загонетања, Стаменковић (STAMENKOVIĆ 2015 ) посматра утицај визуелно-просторних фактора на појмовно сажимање у току решавања загонетке. Истраживање које је обухватило 90 испитаника показује да анимирани визуелни стимуланси убрзавају сажимање концепата, па самим тим и проналажење одговора на загонетку која је задата за одгонетање.
} 
понуђена је; В) одгонетка је позната и слаже се са одгонетком „загонетача”; и Г) одгонетка је позната и и не слаже се са одгонетком ,загонетача”. Ради лакшег прегледа, дати су и подаци о учесталости појављивања одгонетки, за сваку од четири групе одгонетки, као и за сваку одгонетку појединачно.

Пошто ово истраживање има емпиријску компоненту, први циљ рада је да класификује и опише одгонетке које су резултат истих, сличних и различитих тумачења веза између речи и концепата, веза између језика говора и језика мисли. Претпоставка је да одгонетке нису увек у инференцијалној вези са загонетком, већ да могу бити резултат активирања асоцијација. Други циљ рада је представљање неких когнитивно-прагматичких аспеката загонетања и одгонетања и то на основу принципа и претпоставки теорије релеванције.

\section{3. Резултати и дискусија}

Табела 1 показује резултате анализе корпуса. Дате су све одгонетке, разврстане у четири типа: група А, Б, В и Г, на основу критеријума који су описани у претходном делу рада. За сваку одгонетку дат је број појављивања и проценат појављивања у односу на укупан број од 86 испитаних говорника-погађача одговора, у оквиру група којој припадају:

Табела 1. Корпус загонетки и одгонетки

\begin{tabular}{|c|c|}
\hline ЗАГОНЕТКЕ & ОДГОНЕТКЕ (86 испитаника) \\
\hline \multirow[b]{2}{*}{$\begin{array}{l}1 \text { Ако изговориш } \\
\text { моје име више ме } \\
\text { неће бити. }\end{array}$} & (А) одгонетка није позната и није понуђена: 24 \\
\hline & 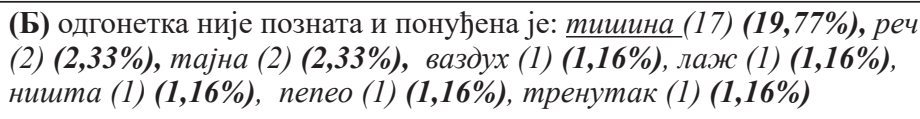 \\
\hline \multirow{3}{*}{ одгонетка: } & $30.23 \%$ \\
\hline & $\begin{array}{l}\text { (B) одгонетка је позната и слаже се са одгонетком „загонетача”: } \\
\text { тишина: } 32 \\
\mathbf{3 7 , 2 1 \%}\end{array}$ \\
\hline & $\begin{array}{l}\text { (Г) одгонетка је позната и и не слаже се са одгонетком } \\
\text {,загонетача": реч (2) (2,33\%), мрак (1) (1,16\%), тајна (1) (1,16\%) } \\
\mathbf{4 . 6 5 \%}\end{array}$ \\
\hline \multirow{2}{*}{$\begin{array}{l}\text { 2. Говори без уста и } \\
\text { језика. }\end{array}$} & (А) одгонетка није позната и није понуђена: 39 \\
\hline & 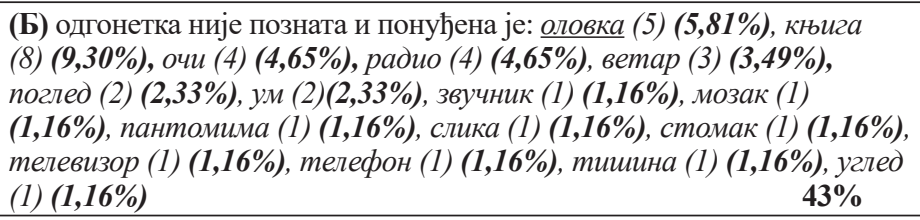 \\
\hline \multirow{2}{*}{ оловка } & (B) одгонетка је позната и слаже се са одгонетком „загонетача”: оловка (5) \\
\hline & $\begin{array}{l}\text { (Г) одгонетка је позната и и не слаже се са одгонетком „загонетача”: } \\
\text { къига (1) }(\mathbf{1 , 1 6 \% ) , ~ о д ј е к ~ ( 1 ) ( 1 , 1 6 \% ) , ~ о ч и ~ ( 1 ) ~}(\mathbf{1 , 1 6 \% ) , ~ p a д и о ~ ( 1 ) ~ ( 1 , 1 6 \% ) , ~} \\
\text { слика (1) }(\mathbf{1 , 1 6 \% )}\end{array}$ \\
\hline
\end{tabular}




\begin{tabular}{|c|c|}
\hline $\begin{array}{l}\text { 3. Ја чувам благо, а } \\
\text { људи мене чувају. }\end{array}$ & (А) одгонетка није позната и није понуђена: 23 \\
\hline одгонетка: & 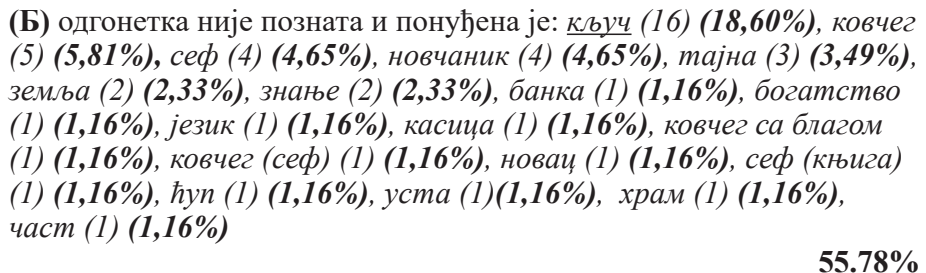 \\
\hline & $\begin{array}{l}\text { (В) одгонетка је позната и слаже се са одгонетком „загонетача”: } \\
\text { кључ (11) } \\
\mathbf{1 2 , 7 9 \%}\end{array}$ \\
\hline & 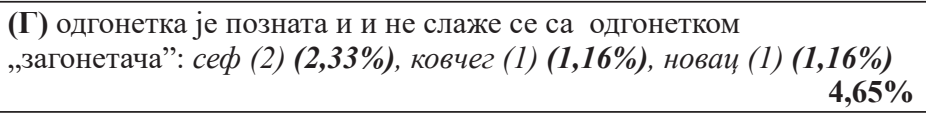 \\
\hline $\begin{array}{l}\text { 4. Никада га није } \\
\text { било, никада га неће }\end{array}$ & (А) одгонетка није позната и није понуђена: 47 \\
\hline $\begin{array}{l}\text { бити, а још увек га } \\
\text { има. }\end{array}$ & 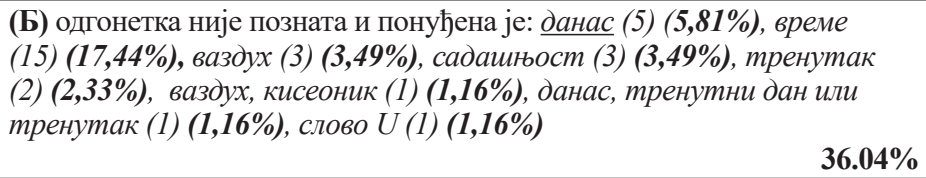 \\
\hline $\begin{array}{l}\text { одгонетка: } \\
\text { данас }\end{array}$ & $\begin{array}{l}\text { (В) одгонетка је позната и слаже се са одгонетком „загонетача”: } \\
\text { данас (6) } \\
\mathbf{6 , 9 8 \%}\end{array}$ \\
\hline & $\begin{array}{l}\text { (Г) одгонетка је позната и и не слаже се са одгонетком „загонетача”: } \\
\text { време (1) }(\mathbf{1 , 1 6 \% ) , ~ с а д ~ ( 1 ) ~ ( 1 , 1 6 \% ) ~}\end{array}$ \\
\hline $\begin{array}{l}\text { 5. Цео дан иде, а } \\
\text { никуд не одмиче. }\end{array}$ & (А) одгонетка није позната и није понуђена: 29 \\
\hline одгонетка: & 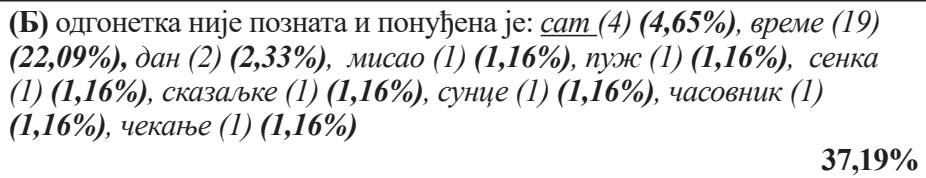 \\
\hline cam & $\begin{array}{l}\text { (В) одгонетка је позната и слаже се са одгонетком „загонетача”: } \\
\text { cam (5) } \\
\end{array}$ \\
\hline & 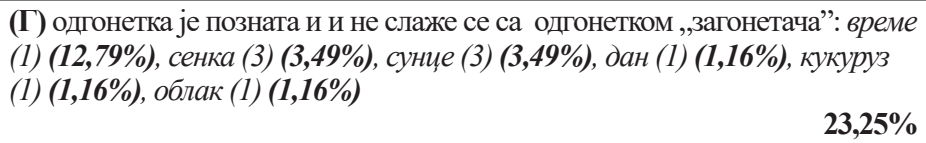 \\
\hline
\end{tabular}

\subsection{1. Општи приказ резултата}

Табела 1 показује да загонетке имају четири врсте одговора. Што се тиче групе А (одгонетка није позната и није понуђена), она показује да говорници нису успели да формирају концепт и да га потом лексикализују. То значи да на континууму између дословне и метафоричне употребе није про- 
нађен денотат/име или персонификовани опис који би могао имати адекватну везу са информацијама и својствима концепата који су кодирани речима у загонеткама. То исто значи да говорници нису успели да опишу и искажу концепт једном речју. Према Сперберу и Вилсоновој (1998: 196), експлицитни садржај исказа је прилагођен на тај начин како би се омогућило извођење импликатура (имплицитног дела значења) које оправдава очекивање релеванције, међутим, у загонеткама нема оваквог прилагођавања, и зато чешће долази до одустајања од потраге за релеванцијом. Проценти показују да су одгонетке често биле неприступачне, и то неприступачне у различитој мери: загонетка 1: 27,91\%; загонетка 2: 45,35\%; загонетка 3: 26,74\%, загонетка 4: $54,65 \%$ и загонетка $5: 33,27 \%$. Резултати за прву и трећу загонетку

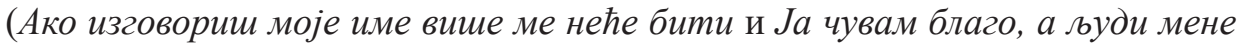
чувају) показују да су те две загонетке биле скоро једнако ментално напорне за решавање, а све остале загонетке било је још теже решавати.

Група Б (одгонетка није позната и понуђена је) показује да су говорници успели да формирају концепт и да га лексикализују као одгонетку, и у том смислу тестирање интерпретативних хипотеза резултирало је ефектом. Говорници-погађачи су на основу претпоставки у вези са концептима који су кодирани речима у загонетки пронашли инференцијалне и/или асоцијативне везе са одгонеткама, тј. речима које кодирају концепте који су стабилни у меморији. Проценти показују да је степен учесталости формирања концепата и лексикализације у групи Б различит, при чему одгонетке на последње две загонетке (Никада га није било, никада га неће бити, а још увек га има и Цео дан иде, а никуд не одмиче) имају скоро исти степен учесталости појављивања: загонетка 1: $30.23 \%$; загонетка 2: $43 \%$; загонетка 3: $55,78 \%$; загонетка 4: $36,04 \%$ и загонетка 5: $37,19 \%$. Треба напоменути да одгонетка часовник на загонетку Цео дан иде, а никуд не одмиче припада групи Б, а не групи В, зато што циљани денотат сат може имати значења и справа за мерење времена и час (као део дана). У групи Б такође треба направити разлику између две подгрупе: прву подгрупу чине одгонетке које се слажу са одгонетком коју је „загонетач” задао, и другу подгрупу чине различите врсте одгонетки које се не слажу са одгонетком коју је „загонетач” задао. О овој разлици биће више речи у следећем делу рада.

Група В (одгонетка је позната и слаже се са одгонетком „загонетача") јесте група која показује да су неке везе између загонетки и одгонетки стабилне у меморији, да су део општег знања и културе: загонетка 1: $37,21 \%$; загонетка 2: $5,81 \%$; загонетка $3: 12,79 \%$; загонетка $4: 6,98 \%$ и загонетка 5 : $5,81 \%$. Најпознатија је прва загонетка (Ако изговориш моје име више ме неће бити), а најмање познате, тј. једнако непознате су друга (Говори без уста и језика) и пета загонетка (Цео дан иде, а никуд не одмиче). Ниједна загонетка није била у потпуности непозната. Ово значи да су претпоставке у вези са загонетком и одгонетком биле узајамно манифестне и да су део заједнич- 
ког когнитивног окружења (енг. cognitive environment), које чини скуп свих чињеница које се могу перципирати или инферирати (SPERBER, WILSON 1995: 39).

Група Г (одгонетка је позната и не слаже се са одгонетком ,загонеmaча") показује да говорници-погађачи могу веровати да знају одговор на загонетку, али да се одговор не уклапа са циљаном одгонетком. Ово може значити да није успостављена стабилна веза између загонетке и одгонетке, те је дошло до другачијег комбиновања претпоставки, али и да можда постоје различити установљени одговори на исту загонетку. Ово је могуће, уколико се узме у обзир континуитет између дословне, лабаве (недословне) и метафоричне употребе речи, као и разлика између језика којим говоримо и језика мисли, који указују на то да се исти концепт може различито исказати, било да је у питању реч или загонетка. Што се тиче процената, за ову групу је карактеристично да прве четири загонетке имају сличне резултате: загонетка 1: 4,65\%; загонетка 2: 5,8\%; загонетка 3: 4,65\%; загонетка 4: 2,32\% и загонетка 5: 23,25\%. У овој групи има примера одгонетки које је понудило више испитаника, као на пример, одгонетка време на загонетку Цео дан иде, а никуд не одмиче. Одгонетка се појављује 11 пута, а такође се појављује и у групи Б, и то 19 пута, што опет указује на узајамну манифестност претпоставки и исти начин подешавања језички кодираног значења и контекста.

У следећем делу рада биће више речи о групи Б (одгонетка није позната и понуђена је) и групи Г (одгонетка је позната и не слаже се са одгонетком „загонетача”), пошто су то групе где су говорници-погађачи различито одговарали на загонетке. То значи да је потрага за релеванцијом била успешна у том смислу да није било одустајања од задатка и да је одговор понуђен, али треба размотрити колико су јасне и приступачне везе између информација и претпоставки у задатим загонеткама и претпоставки у понуђеним одгонеткама.

\subsection{2. Инференцијалне и асоцијативне везе}

Као што је већ наведено, у групи Б (одгонетка није позната и понуђена је) разликују се две подгрупе одгонетки: прву подгрупу чине одговори који се слажу са онима које је ,загонетач” задао, а другу подгрупу чине различите одгонетке које се не слажу са одгонетком коју је ,загонетач” задао. Прва подгрупа показује да претпоставке у вези са речима и концептима у загонеткама нису у толикој мери идиосинкратичне и сакривене да је немогуће погодити денотат који је ,загонетач” сакрио. Проценти показују да је слагање одгонетке ,загонетача” и „погађача” различито заступљено, али и понекада потпуно исто, као што је у случају друге и четврте загонетке (Говори без уста и језика и Никада га није било, никада га неће бити, а још увек га има): загонетка 1: 19,77\%; загонетка 2: 5,81\%; загонетка 3: 18,6\%; загонетка 4: 5,81\% и загонетка 5: 4,65\%. 
Другу подгрупу у оквиру групе Б чине различите врсте одгонетки које се не слажу са одгонетком „загонетача”. Резултати показују да то може бити решење које је понудио само један, али и више од једног испитаника, тако да се може закључити да такви одговори могу бити идиосинкратични и по квантитету и по квалитету, али и да поједини говорници могу имати и исти начин размишљања. Ово не изненађује поготово ако се имају у виду и резултати за прву подгрупу. Осим тога, уколико се одгонетка ретко појављује, то не значи да се не може довести у инференцијалну везу са загонетком, али експлицитни садржај мора бити такав да он контекстуално имплицира имплицитни садржај (SPERBER, WILSON 2008: 92), тј. да одгонетка мора бити изведена на основу комбиновања експлицитног садржаја загонетки и имплицитних премиса којима се долази до закључка. С друге стране, асоцијације су заснивају на претходном повезивању речи било какве врсте (SPERBER, WILSON 2008: 101).

Подгрупа групе Б може се довести у везу са групом Г (одгонетка је позната и не слаже се са одгонетком ,загонетача”). У тој групи налазе се одгонетке који нису исте као циљана одгонетка, иако су се говорниципогађачи изјаснили да им је загонетка била позната. Примера ради, прва загонетка, Ако изговориш моје име, више ме неће бити, спојена је са следећим одговорима у оквиру подгрупе Б: реч (2) (2,33\%), тајна (2) (2,33\%), ваздух (1) (1,16\%), лаж (1) (1,16\%), ништа (1) $(1,16 \%)$, пепео (1) $(1,16 \%)$, тренутак (1) (1,16\%). У оквиру групе $\Gamma$, понуђена су следећа решења: реч (2) (2,33\%), мрак (1) (1,16\%), тајна (1) (1,16\%). Прва два одговора, реч и тајна, показују да су говорници из обе групе успоставили исте везе између речи и концепата у загонетки и одговору на загонетку. Међутим, логичке везе између одгонетке реч и претпоставки у вези са кодираним значењем у загонетки није лако успоставити, односно инференцијална веза није јасна. У том смислу, може се рећи да је ова реч активирана као асоцијација, а не као резултат инференцијалних веза. С друге стране, инференцијална веза између речи тајна и загонетке може се извести, уколико се успостави метонимијска веза са значењем синтагме моје име. Остали одговори, међу којима има и конкретних и апстрактних именица, могу се сматрати асоцијацијама.

У подгрупи групе Б налазе се следећи одговори на загонетку Говори без уста и језика: књига (8) (9,30\%), очи (4) (4,65\%), радио (4) (4,65\%), ветар (3) (3,49\%), поглед (2) (2,33\%), ум (2) (2,33\%), звучник (1) (1,16\%), мозак (1) (1,16\%), пантомима (1) (1,16\%), слика (1) (1,16\%), стомак (1) (1,16\%), телевизор (1) (1,16\%), телефон (1) (1,16\%), тишина (1) (1,16\%), углед (1) $(1,16 \%)$. У групи Г налазе се одгонетке које се појављују и у подгрупи Б: књига (1)(1,16\%), одјек (1)(1,16\%), очи (1) (1,16\%), радио (1) $(1,16 \%)$, слика (1) $(1,16 \%)$. Може се рећи да је ова загонетка изискивала мањи ментални напор јер је било потребно успоставити једну везу између денотата и глаголске предикације. Претходна загонетка има сложенију формално-логичку форму, 
па су и везе између денотата и глаголске предикације сложеније и теже како за одгонетање, тако и за анализу одгонетања. Тако се решења за другу загонетку могу прихватити као различите врсте лабаве употребе (недословне сличности) и употребе метафора, што значи и да се инференцијална веза може успоставити. Ово је лакше када су у питању, на пример, следеће одгонетке: књига, радио, звучник, слика, углед, одјек. Међутим, постоје и речи за које можемо рећи да су пре у асоцијативној вези са речима у загонетки с обзиром на то да се инференцијална веза не може лако разумети. То су, на пример: мозак, ум, типина, стомак. Међу одгонеткама се налазе и одгонетке очи и поглед које је понудило шест говорника. Ове одгонетке су вероватно резултат подсећања на везу између речи очи и изреке Очи су огледало душе.

У оквиру подгрупе групе Б добијени су следећи одговори на загонетку Ја чувам благо, а ьуди мене чувају: ковчег (5) (5,81\%), сеф (4) (4,65\%), новчаник (4) (4,65\%), тајна (3) (3,49\%), земьь (2) (2,33\%), знање (2) (2,33\%), банка (1) (1,16\%), богатство (1) (1,16\%), језик (1) (1,16\%), касица (1) (1,16\%), ковчег са благом (1) (1,16\%), ковчег (сеф) (1) (1,16\%), новач (1) (1,16\%), сеф (кьига) (1) (1,16\%), ћуn (1) (1,16\%), уста (1)(1,16\%), храм (1) $(1,16 \%)$, част (1) $(1,16 \%)$ У групи Г налазе се одговори који се појављују и у подгрупи Б: сеф (2) (2,33\%), ковчег (1) (1,16\%), новач (1) (1,16\%). Неке од понуђених одгонетки настале су као резултат дословног тумачења речи које се често користе у колокацији са глаголом чувати. То су, на пример: ковчег, касица, сеф, новчаник, земља, банка, ћуn, храм. У једном случају дошло је до подешавања одгонетке, односно понуђена су два решења: сеф (кюига). Неки од понуђених одговора су примери лабаве употребе или метафоричне употребе речи, као, на пример: тајна, знање, част. Решења попут речи богатство и новац могу се довести у везу са одгонеткама као што су ковчег, новчаник, сеф (долази до сличног подешавања значења), за које се може рећи да имају јаче инференцијалне везе са речима у задатој загонетки. Одгонетка језик се може разумети као језик којим се говори, тако да се инференцијалне везе могу успоставити, док је друга одгонетка уста спојена са загонетком без јасне инференцијалне везе.

Одговор на четврту загонетку, Никада га није било, никада га неће бити, а још увек га има, је, према „загонетачу”, апстрактна именица данac. У подгрупи Б налазе се следећи одговори: време (15) (17,44\%), ваздух (3) (3,49\%), садашњост (3) (3,49\%), тренутак (2) (2,33\%), ваздух, кисеоник (1) (1,16\%), данас, тренутни дан или тренутак (1) (1,16\%), слово U (1) $(1,16 \%)$. У групи Г налазе се два одговора: време (1) $(1,16 \%)$ и сад (1) $(1,16 \%)$. Претпоставке у загонетки могу се повезати са апстрактним именицама време, садашњост, тренутак, данас, тренутни дан и сад. Уколико се ове речи схвате као примери лабаве употребе и дође до подешавања значења, ове речи могу се сматрати синонимима (нпр. време може имати значење садашње време). То значи да претпоставке у загонетки могу бити 
доведене у везу са различитим речима које се односе на сличне концепте. С друге стране, решења ваздух, кисеоник, слово $U$ резултат су активације асоцијацијативних веза.

На крају, одгонетка Цео дан иде, а никуд не одмиче такође има различита решења. У подгрупи Б налазе се ове одгонетке: време (19) (22,09\%), дан (2) (2,33\%), мисао (1) (1,16\%), пуж (1) (1,16\%), сенка (1) $(1,16 \%)$, сказаљке (1) $(1,16 \%)$, сунце (1) $(1,16 \%)$, часовник (1) $(1,16 \%)$, чекање (1) $(1,16 \%) . \mathrm{y}$ Групи Г налазе се следећи одговори: време (11) (12,79\%), сенка (3) (3,49\%), суние (3) (3,49\%), дан (1) (1,16\%), кукуруз (1) (1,16\%), облак (1) $(1,16 \%)$. Најфрекветнија је реч време у обема групама, што указује на слично размишљање испитаника. Ово може значити да се претпоставке у загонетки повезују са одговарајућим енциклопедијским информацијама о појму кодираном речју време, и долази се до закључка да време стоји, а не одмиче. Слично се може рећи и за закључивање у вези са енциклопедијским информацијама у вези са појмовима кодираним речима дан и сунце, с обзиром на то да се дан и сунце изнова рађају. Овај начин тестирања интерпретативних хипотеза може се везати и за речи сказаљке (ова реч је и у метонимијској вези са речју сат као справа за мерење времена) и часовник (синоним за реч сат као справа за мерење времена), јер подразумевају понављање радње, као и за одгонетку мисао, ако се схвати као размишљање које се понавља. Решења пуж и облак такође могу бити прихваћена као резултат формирања инференцијалних веза уколико се кретање које се описује у загонетки схвати недословно, као споро кретање. Остала решења, сенка, чекање, кукуруз, немају јасне везе са загонетком.

\section{4. Закључак}

Циљ овог рада био је да опише одгонетке, које су резултат истог, сличног и различитог тумачења веза између речи и концепата, а у вези са тим и да представи неке когнитивно-прагматичке аспекте загонетања и одгонетања као специфичног жанра, игре речи и ,играрије духа (ЛАЛЕВИЋ 1995: 151)". Истраживање показује да одгонетање као процес откривања денотата повезивањем информација и претпоставки задатих загонеткама са информацијама и претпоставкама у одгонеткама изискује ментални напор који може имати различите исходе. У складу са стратегијом разумевања (стратегијом најмањег напора), тумачење загонетке може се завршити одустајањем од тестирања интерпретативних хипотеза и од погађања одгонетке. Анализа различитих типова одгонетки показује да може доћи и до другачијих исхода. Када је загонетка непозната, испитаници могу погодити циљани денотат, што указује на то да се информације, односно експлицитни и имплицитни садржаји могу комбиновати на исти начин код „загонетача” и код говор- 
ника-погађача. Такође, испитаници могу понудити иста решења која нису циљани денотат, што опет указује да се информације и претпоставке у вези са загонетком могу повезивати са истим резултатом. Погађање је вероватно олакшано и заједничким когнитивним окружењем, заједничком културом и знањем, енциклопедијским информацијама које имају сличне или исте нивое приступачности у вези са концептима датим у загонеткама.

Потрага за релеванцијом може довести и до одгонетке која је другачија у односу на циљани денотат и другачија у односу на сва остала понуђена решења. Свака одгонетка која је другачија у односу на циљани денотат може бити у слабијој или јачој инференцијалној вези са загонетком, односно претпоставкама и информацијама које загонетка даје. Такође, уколико су инференцијалне везе нејасне или непостојеће, онда се пре може говорити о асоцијацијама или конотацијама у односу на задату загонетку, које могу бити активиране неком компонентом значења речи у загонеткама. С тим у вези, потврђена је хипотеза да се неке одгонетке пре могу назвати асоцијацијама, а не резултатом откривања инференцијалних веза са претпоставкама које су дате у денотацијама које припадају континууму дословне, лавабе и метафоричне екстензије речи. На крају, различити говорници исту реч доводе у везу са различитим концептима, тако да није увек лако направити јасну разлику између чисто асоцијативних и инференцијалних веза.

\section{Цитирана литература}

ALLOTT, Nicholas. Relevance Theory. In: A. Capone, F., Lo Piparo, M Carapezza (Eds.), Perspectives on Linguistic Pragmatics. Book Series: Perspectives in Pragmatics, Philosophy \& Psychology, vol. 2, 2013, Cham et al.: Springer International Publishing Switzerland, 57-98.

BEN-AMOS, Dan. „Solutions to Riddles”. The Journal of American Folklore, vol. 89, Issue 352, 249-254 (1976).

CARSTON, Robyn. Thoughts and Utterances: The Pragmatics of Explicit Communication. Oxford: Blackwell Publishing, 2002.

ДЕСПОТОВИЋ, Милијан. „Загонетке као мисаоно напрегнуће (Гордана Малетић, Није човек, није чигра: избор ауторских загонетки, Лагуна, Београд, 2019)". Детињство/Childhood, Часопис о књижевности за деиу, Година XLV, број 4, (зима 2019.), 98-101.

FAUCONNIER, Gilles and Mark Turner. Conceptual integration networks. In: D. Geeraerts (Ed.), Cognitive Linguistics: Basic Readings. Mouton de Gruyter: Berlin/New York, 303-371, 2006.

JASNOWSKI, Antoni Tadeusz. A Rhetoric of riddles: Riddle solving as an analogy for rhetorical invention. Doctoral Dissertation. ETD collection for University of Nebraska - Lincoln, 1991. 
КАРАЏИЋ, Вук Стефановић. Српске народне приповијетке и загонетке/ скупио их и на свијет Издао Вук Стефановић Караџић. Државно издање, Биоград: Штампарија Краљевине Србије, 1897.

KECSKES, Istvan. Can Intercutural Pragmatics Bring Some New Insight into Pragmatic Theories? In: A. Capone, J.L. Mey (Eds.), Interdisciplinary Studies in Pragmatics, Culture and Society. Book Series: Perspectives in Pragmatics, Philosophy \& Psychology, vol. 4, 2016, Cham et al.: Springer International Publishing Switzerland, 43-69.

КЛЕУТ, Марија. Сложеност једноставних облика народне књижевности. У: М. Вуксановић (Ур.), М. Клеут (приредила). Једноставни облици народне књижевности. Нови Сад: Издавачки центар Матице српске, 2010, 13-21.

ЛАЛЕВИЋ, Миодраг С. Загонетка - играрија духа (Рад XVII конгреса Савеза удружења фолклориста Југославије - Пореч 1970, Загреб, 1972, стр. 549552). У: М. С. Баврлић (Ур.), С. Самарџија (приредила). Српске народне загонетке: антологија. Београд: Гутенбергова галаксија, 1995, 151-156.

MAGACHI, Linet Nyabonyi. A Pragmatic Analysis of Ekegusii Riddles. A research project in partial fulfillment of the requirements for the degree of master of arts, July, 2015. <http://erepository.uonbi.ac.ke/handle/11295/93233> (Последњи преглед 10.04.2021.)

МИЛОШЕВИЋ-ЂОРЂЕВИЋ, Нада. Загонетка (Речник кюижевних термина, Београд, 1985, стр. 935-937). У: М. С. Баврлић (Ур.), С. Самарџија (приредила). Српске народне загонетке: антологија. Београд: Гутенбергова галаксија, 1995, 157-159.

MIŠKOVIĆ-LUKOVIĆ, Mirjana. Semantika i pragmatika iskaza: Markeri diskursa u engleskom jeziku. Beograd: Filološki fakultet, 2006.

RADULOVIĆ, Milica. Naslovi u britanskoj informativnoj štampi u svetlu teorije relevancije. Magistarska teza. Univerzitet u Nišu, Filozofski fakultet, 2011.

RADUlOVIĆ, Milica. Euphemisms in English and Serbian Public Discourse. Doctoral Dissertation. University of Niš, Faculty of Philosophy, 2016.

САМАРЏИЈА, Снежана. Структура и функција усмене загонетке. У: М. С. Баврлић (Ур.), С. Самарџија (приредила). Српске народне загонетке: антологија. Београд: Гутенбергова галаксија, 1995, 5-48.

SIKIMIĆ, Biljana. Etimologija i male folklorne forme. M. Ivić (Ur.), knj. 11. Biblioteka južnoslovenskog filologa: Nova serija, Beograd: Institut za srpski jezik SANU, 1996.

СИКИМИЋ, Биљана. Просторне релације у традиционалним загонеткама. У: М. Делетић, С. Самарџија (Ур.), Жива реч. Зборник у част проф. др Наде Милошевић Ђорђевић, Београд: Балканолошки институт САНУ, 2011, 591-614.

SPERBER, Dan and Deirdre Wilson. Relevance: Communication and Cognition, 2nd edition. Oxford UK \& Cambridge USA: Blackwell, 1995.

SPERBER, Dan and Deirdre Wilson. The Mapping between the Mental and the Public Lexicon. In: P. Carruthers, J. Boucher (Eds.), Language and Thought: Interdisciplinary Themes. Cambridge: Cambridge University Press, 1998, 184 200. 
SPERBER, Dan and Deirdre Wilson. A Deflationary Account of Metaphor. In: R.W. Gibbs, JR. (Ed.), The Cambridge Handbook of Metaphor and Thought. Cambridge: Cambridge University Press, 2008, 84-105.

STAMENKOVIĆ, Dušan. "The Effects of Animated Visual Stimuli of the Process of Conceptual Blending in Riddle Solving”. Facta Universitatis: Linguistics and Literature, vol. 13, No 1, 11-19 (2015). DOI: http://dx.doi.org/10.2139/ ssrn.2496010.

HUSSEIN Juma'a Qadir and Imran Ho Abdullah. "The Role of Cognitive Context in the Interpretation of Riddles: A Relevance Theory Perspective". Pertanika Journal Social Sciences \& Humanities, 24 (S): 11-20 (2016).

\section{Извори}

Загонетке: <https://www.boske.rs/stranice/zagonetke.html> (Последњи преглед 10.04.2021.)

Milica M. Radulović

\section{COGNITIVE-PRAGMATIC ASPECTS OF RIDDLES AND SOLUTIONS TO RIDDLES}

The article discusses some cognitive-pragmatic aspects of the riddle, a short literary and folklore form that consists of the verbal acts of posing and solving riddles. Posing and solving riddles can be defined as discovering not highly accessible connections between the assumptions and information given by the riddle and the assumptions and information given by the solution to the riddle. The theoretical background is based on Sperber and Wilson's (1995) principles of relevance and the claim that there is no discontinuity between loose and metaphorical uses of language. The theoretical postulates are grounded in the conceptualization that communication does not only include linguistic coding and decoding, but it also involves making contextual implications by means of which optimally relevant meanings and interpretations are derived. The analysis is based on a corpus that includes the solutions to five Serbian riddles, and the examples for the analysis were collected by means of a survey completed by 86 native speakers of Serbian. The article tests the hypothesis that the solutions to the riddles are not always the result of the discovery of the inferential ties between the assumptions given in the riddle and the assumptions given in the solution to the riddle, but they can also be the result of the activation of associations. The aim is to describe the solutions to the riddles, which are the result of the same, similar, or different interpretations of the connections between the words and concepts in the riddles. Another more general aim is to describe some cognitive-pragmatic aspects of posing and solving riddles. The results show that the solutions to all the five riddles can be classified into four different groups. Also, the research confirms the hypothesis that some 
riddles can be identified as associations rather than the result of discovering the inferential ties between the riddle and the solution.

Keywords: riddle, solution, cognitive-pragmatic aspects, relevance theory, word, concept, loose use of language, metaphor. 